\title{
ANALISA BUCK CONVERTER DAN BOOST CONVERTER PADA PERUBAHAN DUTY CYCLE PWM DENGAN MEMBANDINGKAN FREKUENSI PWM 1,7 Khz DAN 3,3 Khz
}

\author{
Hendi Matalata $^{1}$, Leily W Johar ${ }^{2}$
}

\begin{abstract}
Buck-Boost Converters are electric power supply device for raising and lowering the voltage DC (Direct Current) power supply equipment according to needs of the electrical load, this research is designed to Buck-Boost Converter and Converter on the 12 Volt power supply, the design of a Buck Converter power supply derived 5 Volt, 6Volt and 6 Volt design while the Boost Converter power supply 12 Volt offered up to 16 Volt, 19 Volt and 22 Volts in a way set the duty cycle of PWM frequency settings in $1.7 \mathrm{Khz}$ and $3.3 \mathrm{Khz}$. Results research indicates the State of the differences in each frequency in the set output voltage ripple shape obtained is different, however, in the design of this research have been successfully carried out as expected.
\end{abstract}

Keywords: buck converter, boost converter, change in duty cycle

\section{PENDAHULUAN}

Perkembangan teknologi dalam meregulasi tegangan catu daya terhadap perangkat-perangkat beban listrik dewasa ini sudah tidak terelakan lagi, untuk itu penggunaan komponen saklar daya dan rangkaian elektronika daya telah mampu menghasilkan sistem penyedia daya tegangan searah, yang dihasilkan melalui konversi tegangan DC (Direct Current) masukan ke bentuk tegangan DC keluaran yang lebih tinggi atau lebih rendah. Konversi tegangan DC ini biasa disebut DC-DC converter. Pada perkembagannya, penerapan DC-DC converter telah memungkinan suatu perangkat elektronik dapat berfungsi dengan menggunakan sumber energi baterai yang berukuran kecil dimana tegangan keluarannya dapat diubah-ubah sesuai kebutuhan pemakaian.

Secara umum beberapa jenis rangkaian DC-DC converter yaitu buck converter, boost converter dan buckboost converter. Untuk menaikan tegangan yang lebih besar dari

\begin{tabular}{l}
\hline $\begin{array}{c}1 \\
\text { Dosen Teknik }\end{array}$ Listrik Universitas \\
$\begin{array}{c}\text { Batanghari Jambi } \\
2 \text { Dosen Teknik }\end{array}$ Listrik Universitas \\
Batanghari Jambi
\end{tabular}

tegangan sumbernya dapat menggunakan boost converter, untuk menurunkan tegangan yang lebih kecil dari tegangan sumber dapat menggunakan buck converter, jika menginginkan tegangan yag bisa diatur lebih kecil atau lebih tinggi dari tegangan sumber dapat menggunakan buck dan boost converter.

System buck dan boost converter merupakan salah satu regulator dc tipe switching non-isolated yang dapat menjawab kebutuhan akan sebuah sumber tegangan keluaran variabel. Dengan sistem buck dan boost converter, nilai tegangan keluaran dapat diatur untuk lebih besar maupun lebih kecil dari nilai tegangan masukan dengan mengatur frekuensi dan besar lebar pulsa (duty cycle). Duty cycle dibangkitkan dengan menggunakan sinyal PWM (pulse Width Modulation) untuk mengatur switch pada buck dan boost converter.

Berdasarkan masalah yang dikemukakan di atas, penulis akan menganalisa frekuensi switching dan besar duty cycle terhadap tegangan keluaran pada buck dan boost converterI. 


\section{Buck dan Boost Converter \\ Buck Converter}

Defenisi buck converter menurut

Agus Setyawan, dkk (104) adalah sebagai berikut:

"Buck converter adalah jenis dc-dc converter yang memiliki output tegangan yang lebih kecil dari tegangan input".

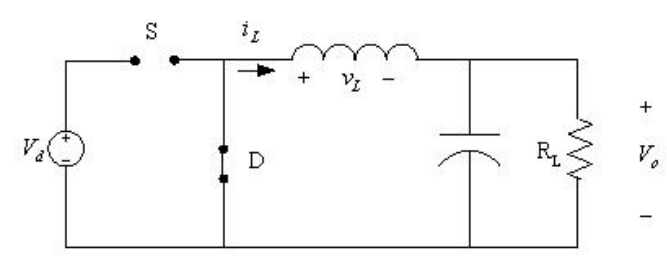

Gambar 1 Rangkaian dasar buck converter

Ketika saklar tertutup, diode dalam keadaan reverse sehingga sinyal input menuju induktor dan terjadi penyimpanan energi.

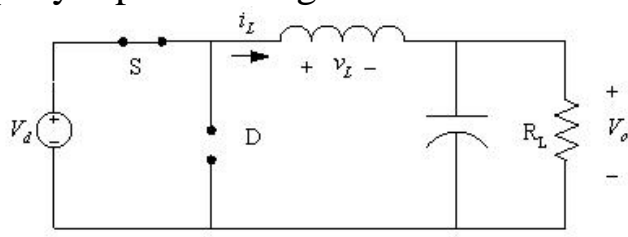

Gambar 2 Rangkaian buck converter kondisi saklar tertutup

dari gambar diatas secara matematis dapat ditulis sebuah persamaan sebagai berikut:

$V_{L}=V_{d}-V_{0}=L \frac{d i_{L}}{d t}(1)$

$\frac{d i_{L}}{d t}=\frac{V_{d}-V_{0}}{L}(2)$

$\frac{d i_{L}}{d t}=\frac{\Delta_{i L}}{\Delta t}=\frac{\Delta_{i L}}{D T}=\frac{V_{d}-V_{O}}{L}(3)$

$\Delta_{i L \text { closed }}=\left(\frac{V_{d}-V_{0}}{L}\right) \cdot D T(4)$

Sedangkan saat kondisi saklar terbuka diode menjadi forward bias sehingga ada aliran tegangan yang melalui kapasitor.

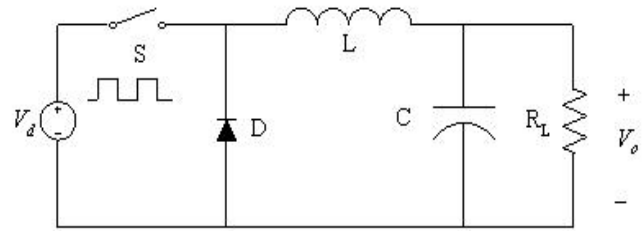

Gambar 3 Rangkaian buck converter kondisi saklar terbuka

dari gambar diatas secara matematis dapat ditulis sebuah persamaan sebagai berikut:

$V_{L}=-V_{o}=L \frac{d i_{L}}{d t}(5)$

$\frac{d i_{L}}{d t}=-\frac{-V_{O}}{L}(6)$

$\frac{d i_{L}}{d t}=\frac{\Delta_{i L}}{\Delta t}=\frac{\Delta_{i L}}{(1-D) \cdot T}=\frac{-V_{o}}{L}(7)$

$\Delta_{i L \text { opened }}=\left(-\frac{V_{0}}{L}\right) \cdot(1-D) \cdot T(8)$

Besarnya duty cycle agar tegangan output sesuai yang di harapkan adalah sebagai berikut :

$\frac{V_{o}}{V_{d}}=D(9)$

$\frac{\Delta V_{0}}{V_{o}}=\frac{1-D}{8 L C f^{2}}(10)$

Nilai induktansi yang dibutuhkan untuk membuat sebuah buck converter adalah berdasarkan persamaan berikut :

$L_{\min }=\frac{(1-D) R}{2 f}(11)$

dimana :

$L_{\min }=$ Nilai Induktansi minimum

$\mathrm{D}=$ duty cycle

$\mathrm{R}=$ resistansi

$\mathrm{F}=$ frekuensi

\section{Boost Converter}

Defenisi Boost converter menurut Melzi Ambar Marta, dkk (2016 : 22) adalah sebagai berikut:

"Boost converter merupakan konverter DC-DC yang berfungsi untuk menaikan tegangan”. 


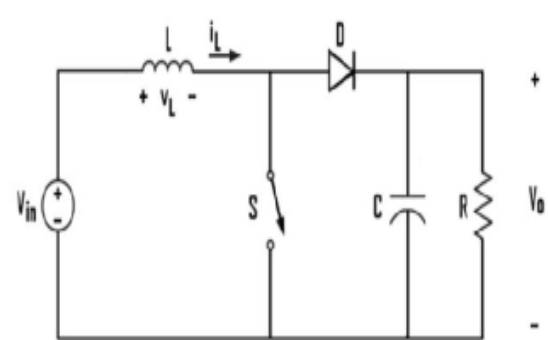

Gambar 4 Rangkaian boost converter

Gambar 4 diatas merupakan gambar rangkaian boost coverter, untuk mempermudah dalam menganalisa rangkaian boost, gambar 2.5 berikut ini merupakan state dari rangkaian boost pada state $\mathrm{ON}$ dan state OFF.

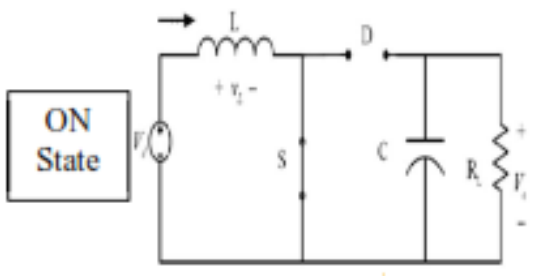

a. State $O N$

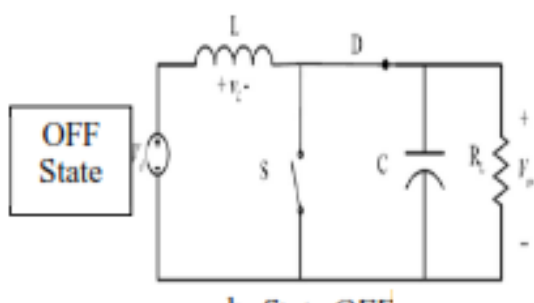

b. State $O F F$

Gambar 5 Rangkaian boost pada saat a.state ON dan b. state OFF

Untuk mendesain boost converter perlu ditetapkan beberapa variabel, yaitu tegangan masukan, tegangan keluaran, arus keluaran, frekuensi switching, ripple tegangan keluaran, dan ripple arus masukan. Dalam menentukan besarnya nilai induktor dan kapasitor dapat menggunakan persamaan berikut :

$C=\frac{V_{0} \cdot D}{R \Delta V_{o} \cdot f}(12)$

$L=\frac{V_{\text {in }} \cdot D(1-D)}{f . \Delta I_{\text {in }}}(13)$

Dimana :

$\mathrm{v}_{\mathrm{o}}=$ Tegangan keluaran
$\mathrm{V}_{\text {in }}=$ Tegangan masukan

$\mathrm{D}=$ Duty cycle

$\mathrm{L}=$ Nilai induktor (induktansi)

$\Delta \mathrm{I}_{\mathrm{in}}=$ Riple arus

$\mathrm{F}=$ frekuensi switching

$\mathrm{C}=$ Nilai kapasitor

\section{Pulse Width Modulation (PWM)}

Defenisi PWM menurut Ida Bagus Fery Citarsa,dkk (2015 : 02) adalah sebagai berikut:

"PWM adalah sebuah metode yang digunakan untuk mengatur jumlah daya (power) yang dialokasikan ke beban tanpa harus menimbulkan rugi-rugi daya pada rangkaian pengendali beban tersebut".

Prinsip dasar pembangkitan sinyal PWM pada umumnya dilakukan dengan membandingkan dua buah sinyal dengan frekuensi berbeda seperti yang diperlihatkan pada Gambar 6 dan Gambar 7 dimana gambar tersebut memperlihatkan perbandingan gelombang modulasi yang berupa gelombang sinus dengan gelombang carrier yang berupa sinyal segitiga. Hasil perbandingan kedua sinyal tersebut menghasilkan pulsa dengan lebar yang berbeda-beda.

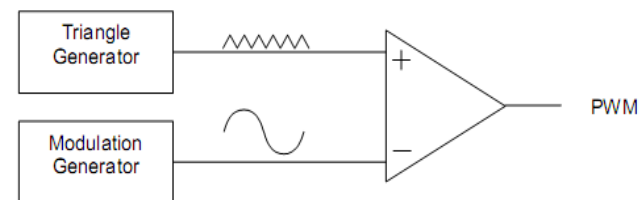

\section{Gambar 6 Proses Modulasi Sinyal PWM}

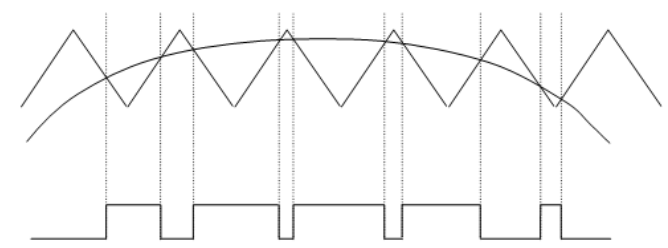

Gambar 7 pembagkitan pulsa PWM

Sinyal PWM pada umumnya memiliki amplitudo dan frekuensi dasar yang tetap, namun memiliki lebar pulsa yang bervariasi. Lebar Pulsa PWM berbanding lurus dengan 
amplitudo sinyal asli yang belum termodulasi. Artinya, Sinyal PWM memiliki frekuensi gelombang yang tetap namun duty cycle bervariasi (antara 0\% hingga 100\%).

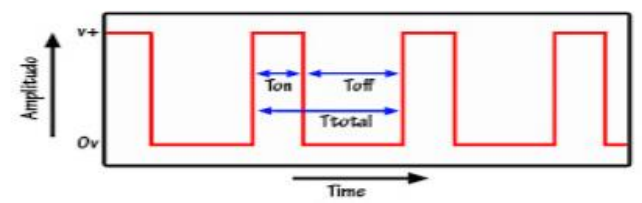

Gambar 9 signal PWM

$T_{\text {total }}=T_{\text {on }}+T_{\text {off }}(14)$

$D=\frac{T_{\text {on }}}{T_{\text {total }}}(15)$

$V_{\text {out }}=D \times V_{\text {in }}(16)$

Dimana :

$\mathrm{T}_{\text {on }}=$ waktu pulsa high

$\mathrm{T}_{\text {off }}=$ waktu pulsa low

$\mathrm{D}=$ duty cycle adalah lama nya

pulsa high dalam satu priode

Perancangan

Model Perancangan

Berikut adalah model perancangan pada masing-masing rangkaian baik pada rangkaian buck converter maupun rangkaian boost converter,

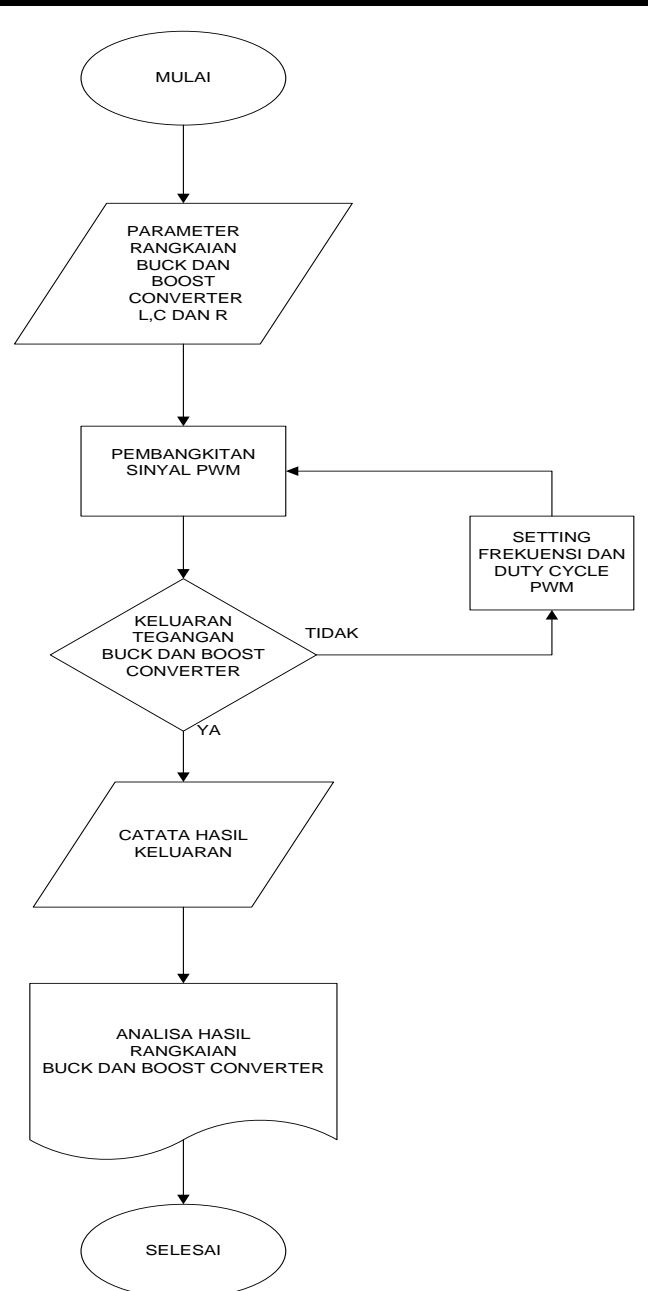

Gambar 9 Flowchart Penelitian

Parameter-parameter Perangkat Keras Rangkaian Buck Converter dan Boost Converter

Pada rangkaian daya Buck converter dan Boost converter yang dirancang, komponen saklar daya menggunakan MOSFET IRF 740 B sedangkan induktor menggunakan jenis batang ferrit dengan nilai $3,4 \mathrm{mH}$, untuk kapasitansi kapasitor yang digunakan 47 uf/50 volt. Gambar 10 dan gambar 11 dibawah memperlihatkan masing-masing rangkaian daya Buck Converter dan Boost Converter. 


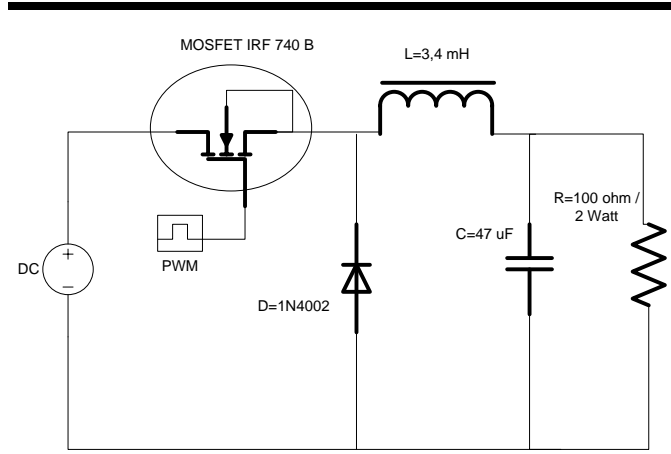

Gambar 10 Rangkaian Daya Buck Converter

Pada gambar 10 rangkaian daya Buck Converter yang ditunjukan diatas setting duty cycle PWM diatur masingmasing 30\%, 50\% dan 70\%, dengan besar sinyal frekuensi-nya $1,7 \mathrm{KHz}$ dan 3 KHz. Dari setting tersebut akan didapat bentuk ataupun hasil keluaran berupa tegangan DC dari rangkaian yang akan dijadikan target pada penelitian.

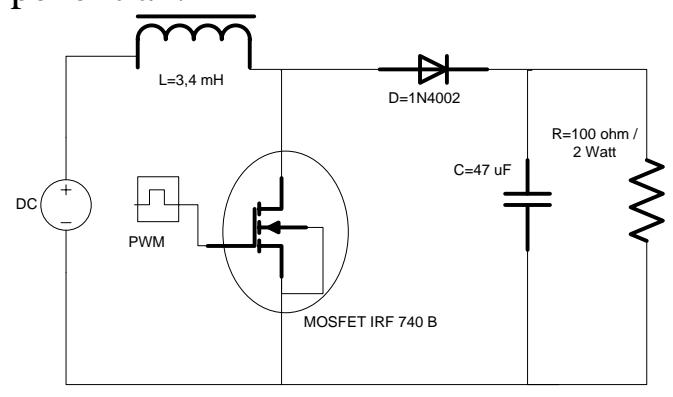

\section{Gambar 11 Rangkaian Daya Boost} Converter

Pada gambar 11 rangkaian daya Boost Converter yang ditunjukan diatas setting PWM yang digunakan sama seperti pada rangkaian daya Buck Converter sehingga nantinya didapat seberapa besar pengaruh dari duty cycle dan PWM dari masing-masing rangkaian.

\section{Pembangkitan Sinyal PWM}

Untuk membangkitkan sinyal PWM, pada penelitian menggunakan PWM analog dengan menggunakan IC TL $494 \mathrm{~L}$, rangkaian pembangkitan dari sinyal PWM tersebut diperlihatkan pada gambar 12 dibawah.

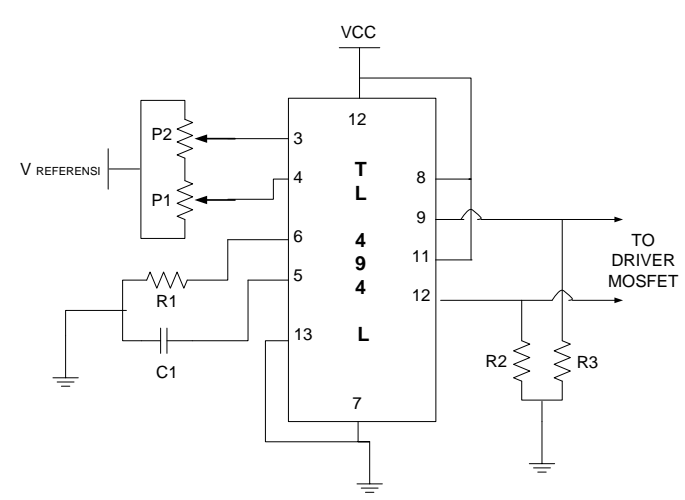

\section{Gambar 12 Rangkaian Pembangkitan Sinyal PWM}

Konfigurasi kaki-kaki IC (Integrated Circuit) pada gambar 12 diatas mempunyai fungsi dan karakteristik masing-masing, dimana pada kaki 3 dan kaki 4 terhubung dengan P1 dan P2 (potensio) untuk pengaturan besar duty cycle keluaran PWM IC TL 494 L (kaki 9 dan kaki 12) kemudian kaki 6 dan kaki 5 pada IC yang terhubung dengan R1 dan $\mathrm{C} 1$ berfungsi untuk pengaturan frekuensi keluaran PWM IC TL 494 L, sedangkan R2 dan R3 pada keluaran kaki IC berfungsi sebagai beban kontrol PWM IC TL 494 L.

Sinyal PWM yang dibangkitkan IC TL $494 \mathrm{~L}$ ini kemudian diperuntukan sebagai masukan dari rangkaian Driver gate MOSFET, seperti diperlihatkan pada gambar 13 dibawah. Rangkaian gate driver ini dibangun dengan menggunakan IC IR2110.

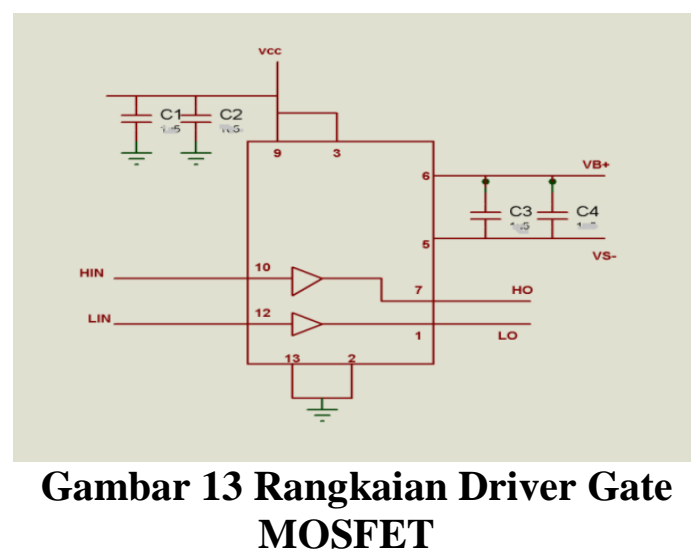


Dari gambar 13 diatas HIN dan LIN adalah masukan dari IC IR 2110 dimana masukan ini diperoleh dari keluaran IC TL 494 L sedangkan HO dan LO adalah keluaran dari IC IR 2110 yang diperuntukan sebagai masukan dari gate MOSFET pada rangkaian daya Buck Converter dan rangkaian daya Boost Converter.

\section{HASIL DAN PEMBAHASAN}

Hasil keseluruhan perakitan perangkat keras yang dibangun diperlihatkan pada gambar 14 dibawah.

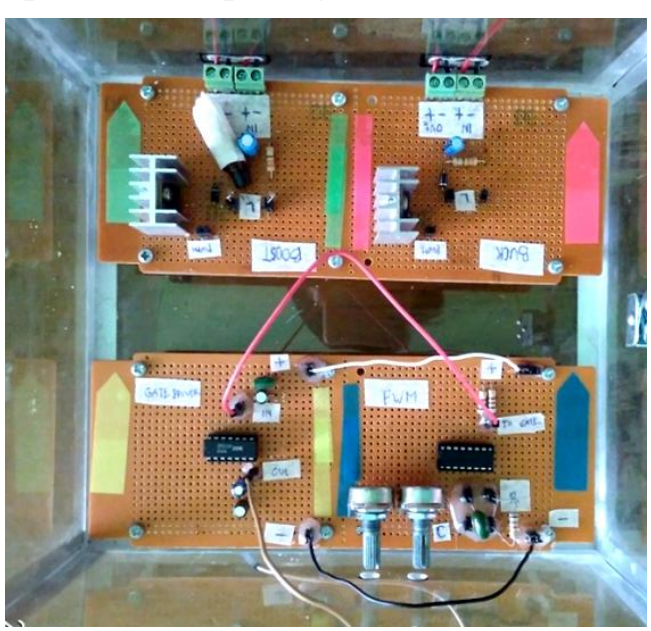

Gambar 14 Rangkaian Keseluruhan Perangkat Keras

Buck converter pada saat frekuensi $1,7 \mathrm{Khz}$

Seperti dijelaskan sebulum-nya bahwa pada setting frekuensi besar duty cycle diatur $30 \%, 50 \%$ dan $70 \%$. sedangkan tegangan masukan yang akan diturunkan (Buck) adalah 12 volt. gambar 15, gambar 16 dan gambar 17 dibawah memperlihatkan bentuk atau besar sinyal PWM keluaran dari rangkaian Buck converter.

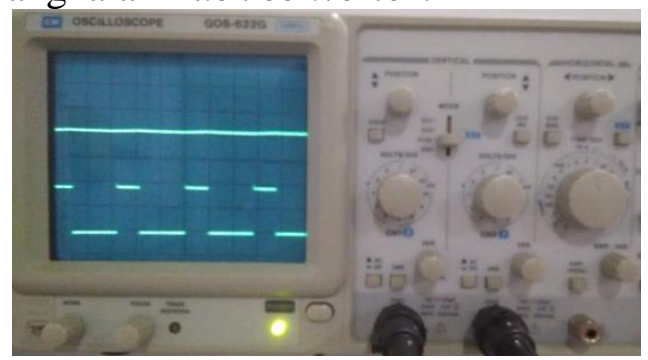

Gambar 15 Bentuk atau Besar sinyal PWM 30\% dan Keluaran Buck converter

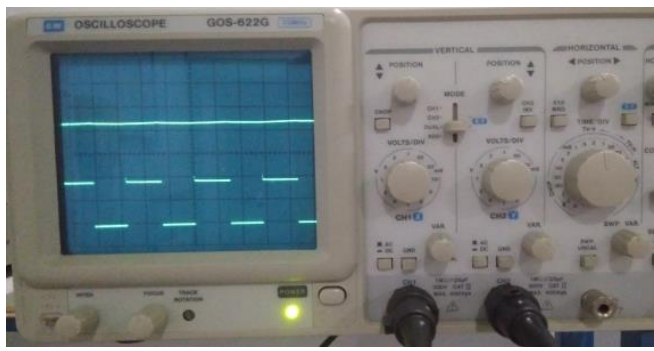

Gambar 16 Bentuk atau Besar sinyal PWM 50\% dan Keluaran Buck converter

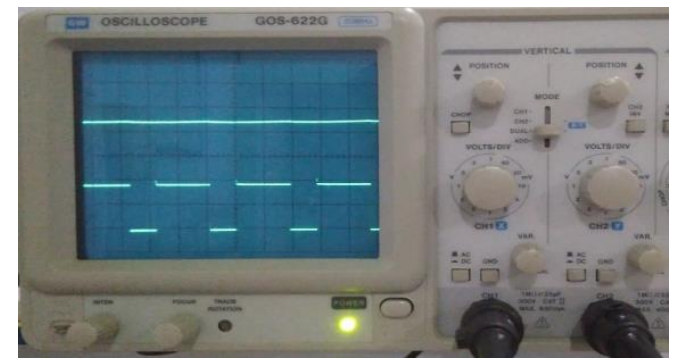

Gambar 17 Bentuk atau Besar sinyal PWM 70\% dan Keluaran Buck converter

Pada gambar 15, gambar 16 dan gambar 17 diatas setting pengukuran pada osciloscop yang dilakukan adalah sebagai berikut:

1. Volts/Div $\mathrm{CH} 1=\mathrm{x} 5$

2. Volts/Div $\mathrm{CH} 2=x 5$

3. Time $/$ Div $=x 0,1 \mathrm{~ms}$

4. Probe $\mathrm{CH} 1=\mathrm{x} 1$

5. Probe $\mathrm{CH} 2=\mathrm{x} 1$

Buck converter pada saat frekuensi 3,3 Khz

Adapun langkah-langkah pengambilan data pada setting 3,3 Khz dilakukan sama seperti pengambilan data pada frekuensi 1,7 Khz, hasil dari rangkaian daya Buck converter diperlihatkan gambar 18, gambar 19 dan gambar 20 dibawah.

Analisa Buck Converter dan Boost Converter pada Perubahan Duty Cycle Pwm dengan Membandingkan Frekuensi PWM 1,7 Khz dan 3,3 Khz 


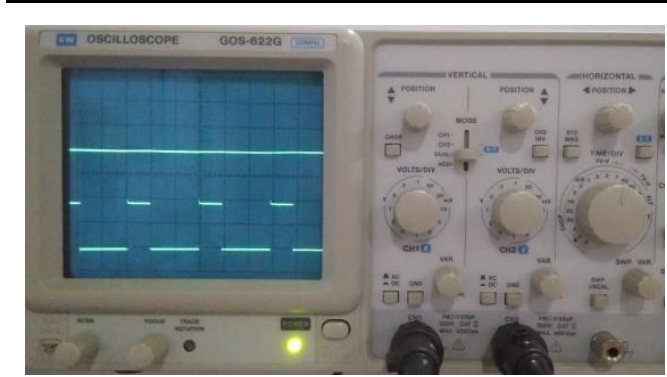

Gambar 18 Bentuk atau Besar sinyal PWM 30\% dan Keluaran Buck converter

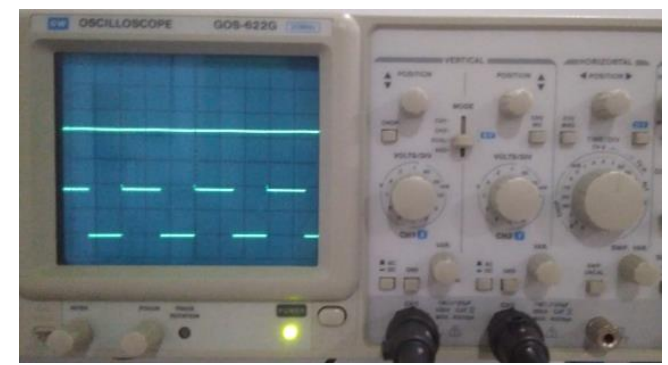

Gambar 19 Bentuk atau Besar sinyal PWM 50\% dan Keluaran Buck converter

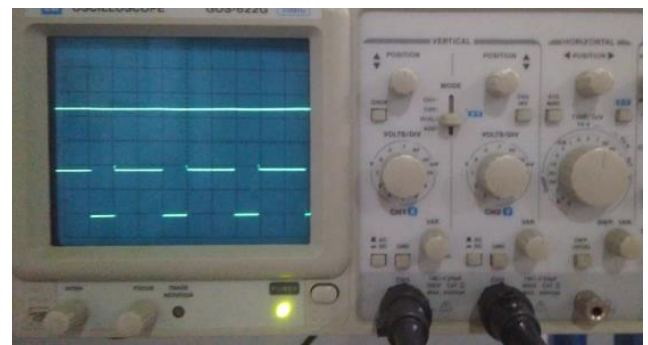

Gambar 20 Bentuk atau Besar sinyal PWM 70\% dan Keluaran Buck converter

Pada gambar 18, gambar 19 dan gambar 20 diatas setting pengukuran pada osciloscop yang dilakukan sama seperti pengukuran frekuensi $1,7 \mathrm{Khz}$ hanya saja Time/Div disetting x50 us.

Hasil keseluruhan data penelitian yang dilakukan pada rangkaian daya Buck converter diperlihatkan pada tabel 1 dibawah.
Tabel 1 Tegangan Keluaran dan Duty Cycle Pengukuran

\begin{tabular}{ccccc}
\hline & \multicolumn{2}{c}{$1,7 \mathrm{Khz}$} & \multicolumn{2}{c}{$3,3 \mathrm{Khz}$} \\
No & $\begin{array}{c}\text { Duty } \\
\text { Cycle } \\
(\%)\end{array}$ & $\begin{array}{c}\text { Vout } \\
\text { (Volt) }\end{array}$ & $\begin{array}{c}\text { Duty } \\
\text { Cycle }\end{array}$ & Vout \\
\hline 1 & 30 & 5 & 30 & 5 \\
2 & 50 & 6 & 50 & 6 \\
3 & 70 & 7 & 70 & 7 \\
\hline
\end{tabular}

Boost converter pada saat frekuensi 1,7 Khz

Pada rangkaian daya Boost converter setting frekuensi besar duty cycle diatur sama seperti Buck converter. Dalam hal tegangan masukan yang akan dinaikan (Boost) adalah 12 volt. gambar 21, gambar 22 dan gambar 23 dibawah memperlihatkan bentuk atau besar sinyal PWM keluaran dari rangkaian Boost converter.

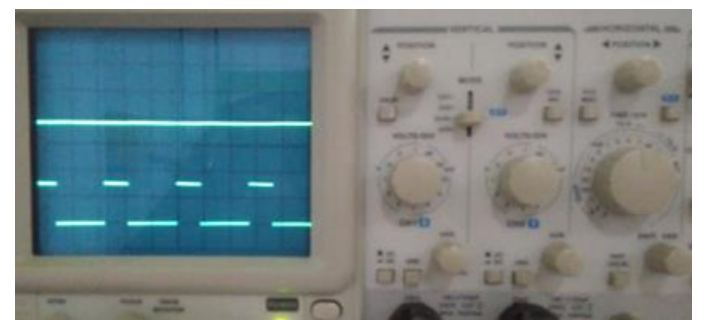

Gambar 21 Bentuk atau Besar sinyal PWM 30\% dan Keluaran Boost converter

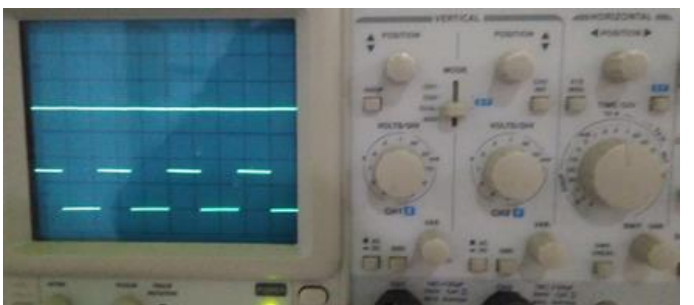

Gambar 22 Bentuk atau Besar sinyal PWM 50\% dan Keluaran Boost converter

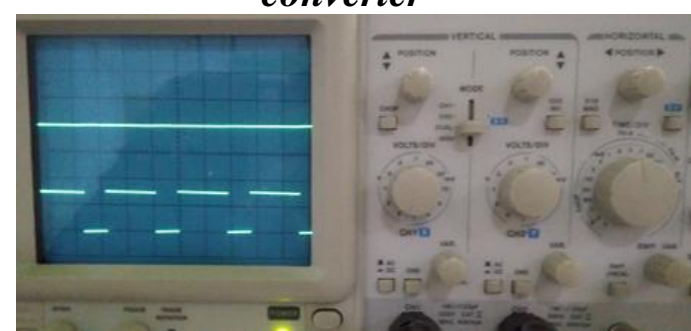

Gambar 23 Bentuk atau Besar sinyal PWM 70\% dan Keluaran Boost converter

Analisa Buck Converter dan Boost Converter pada Perubahan Duty Cycle Pwm dengan Membandingkan Frekuensi PWM 1,7 Khz dan 3,3 Khz 
Pada gambar 21, gambar 22 dan gambar 23 diatas setting pengukuran pada osciloscop yang dilakukan adalah sebagai berikut:
1. Volts/Div $\mathrm{CH} 1=\mathrm{x} 5$
2. Volts/Div $\mathrm{CH} 2=\mathrm{x} 2$
3. Time $/ \mathrm{Div}=x 0,1 \mathrm{~ms}$
4. Probe $\mathrm{CH} 1=\mathrm{x} 1$
5. Probe $\mathrm{CH} 2=\mathrm{x} 10$

yang mana untuk pengukuran sinyal PWM menggunakan $\mathrm{CH} 1$ sedangkan $\mathrm{CH} 2$ digunakan untuk pengukuran keluaran rangkaian daya Boost Converter

Boost converter pada saat frekuensi 3,3 Khz

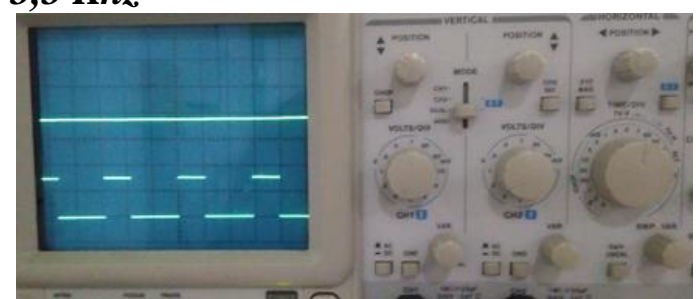

Gambar 24 Bentuk atau Besar sinyal PWM 30\% dan Keluaran Boost converter

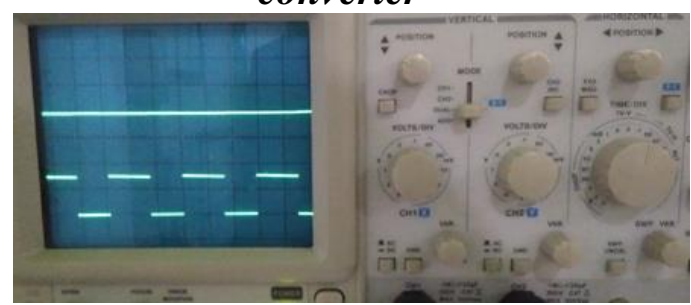

Gambar 25 Bentuk atau Besar sinyal PWM 50\% dan Keluaran Boost converter

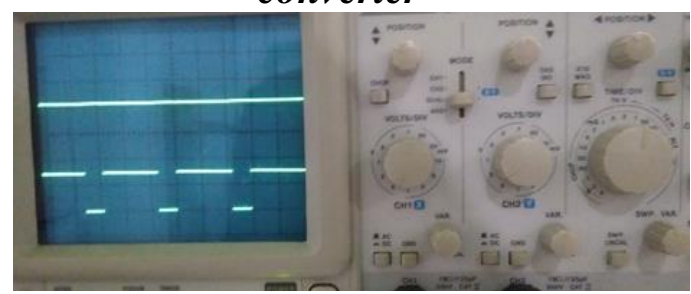

Gambar 26 Bentuk atau Besar sinyal PWM 70\% dan Keluaran Boost converter

Pada gambar 24, gambar 25 dan gambar 26 diatas setting pengukuran pada osciloscop yang dilakukan sama seperti pengukuran pada frekuensi 1,7
Khz hanya saja Time/Div disetting x50 us.

Hasil keseluruhan data penelitian yang dilakukan pada rangkaian daya Boost converter diperlihatkan pada tabel 2 dibawah.

Tabel 2 Tegangan Keluaran Terhadap Perubahan Duty Cycle PWM

\begin{tabular}{ccccc}
\hline & \multicolumn{2}{c}{$1,7 \mathrm{Khz}$} & \multicolumn{2}{c}{$3,3 \mathrm{Khz}$} \\
No & $\begin{array}{c}\text { Duty } \\
\text { Cycle } \\
(\%)\end{array}$ & $\begin{array}{c}\text { Vout } \\
\text { (Volt) }\end{array}$ & $\begin{array}{c}\text { Duty } \\
\text { Cycle }\end{array}$ & Vout \\
\hline 1 & 30 & 16 & 30 & 16 \\
2 & 50 & 19 & 50 & 19 \\
3 & 70 & 22 & 70 & 22 \\
\hline
\end{tabular}

Pengaruh Perbedaan Frekuensi dan Variasi Duty Cycle pada Buck dan Boost Converter.

secara keseluruan pengaruh frekuensi dan besar duty cycle bila dilihat dari bentuk yang ditampilkan osciloscop terdapat ripple yang berbeda-beda, Gambar 27 dibawah menunjukan tegangan catu daya ketika diturunkan (buck) maupun ketika dinaikan (boost)

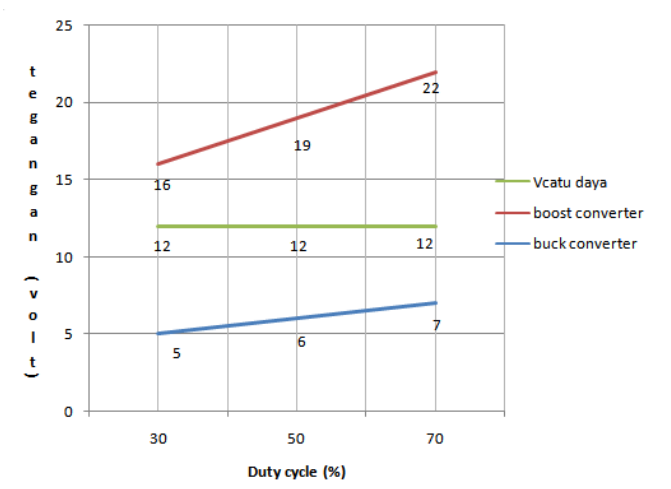

Gambar 27 Grafik Keluaran Catu Daya pada Buck dan Boost Converter

\section{SIMPULAN}

1. Perancangan Buck Converter maupun Boost Converter telah berhasil dilakukan

2. Rangkaian Daya Buck Converter maupun Boost Converter terdapat 
ripple yang lebih halus jika

frekuensi-nya lebih besar.

3. Nilai kapasitor dan resistor yang terdapat pada rangkaian daya Buck Converter dan Boost Converter mempengaruhi nilai ripple keluaran tegangan pada frekuensi tertentu.

\section{DAFTAR PUSTAKA}

Design Calculation For Buck-Boost Converters by Texas Instrumen, 2012.

Dr.Awang/Dr.Zainal, Power

Electronics and Drivers, 2009.

TL494 Pulse-Width-Mosulation

Control Circuits by Texas

Instrumen, 2017.

Karim EL khadiri and Hassan Qjidaa,

"Inverting Buck-Boost DCDC

Converters Design Challenges,"

IJESA Vol4,No.1,March 2014. 